\title{
Evaluation of the Anti-Motility-Related Diarrhoeal Activity of the Sage Tea Salvia officinalis L. in Laboratory Mice
}

\author{
Assist. Prof. Dr. Jafar Abbas Issa AL-Maamori \\ Department of Biology, College of Science \\ Wasit University \\ Wasit Province, AL-Kut city, Iraq
}

Tel: 964-781-907-9920_E-mail: almaamori@yahoo.com

Received: June 9, 2011 Accepted: July 1, 2011 doi:10.5539/ijb.v3n4p36

\begin{abstract}
Sage tea Salvia officinalis L. extract was evaluated scientifically for its anti-motility-related diarrhoeal effect of mice in current study by using castor oil as laxative agent-induced diarrhoea model against loperamide as standard anti-motility-related diarrhoeal drug. Fifteen male mice were used and divided into three groups (5 animals per group) ${ }^{+\mathrm{ve}}$ control, $^{-\mathrm{ve}}$ control (loperamide treatment) and sage tea treatment groups respectively. The results reported a reduction in purging index (137.78), significantly decreasing of the latency period $(0.90 \pm 0.10)$ and number of stools $(1.24 \pm 0.19)$ of $S$. officinalis L. sage tea treatment group as compared to ${ }^{-v e}$ control (loperamide) $(153.85),(2.00 \pm 0.32)$ and $(1.30 \pm 0.20)$ and $^{\text {tve }}$ control groups $(254.72),(5.40 \pm 0.81)$ and $(2.12 \pm$ 0.10) respectively. Concludes from these findings that an inhibitory action of motility-related diarrhea effect of Salvia officinalis L. extract is evident from the experimental model like- castor oil induced diarrhea may be attributed to therapeutic properties of this plant which contains pharmacologically active substances with anti-motility-related diarrheal properties.
\end{abstract}

Keywords: Motility -related diarrhea, Castor oil, Sage tea S. officinalis L., Loperamide

\section{Introduction}

Diarrhoea is defined by the World Health Organization as having 3 or more loose or liquid bowel movement per day, or as having more stools than is normal for that person (WHO, 2011). It is a common cause of death in developing countries and the second most common cause of infant deaths worldwide. The loss of fluids through diarrhoea can cause dehydration and electrolyte imbalances. In 2009 diarrhoea was estimated to have caused 1.1 million deaths in people aged 5 years and over and 1.5 million deaths in children under the age of 5 years (WHO, 2009). As well as, according to the World Health Report WHO (2004), diarrhoea is the cause of $3.3 \%$ of all deaths. In young children, it can lead to death due to dehydration and in survivor's impaired growth and malnutrition. In adults, while the impact is less severe, it nevertheless can lead to nutritional deficiencies especially in the case of persistent diarrhoea.

Diarrhoea varied from the secretory, osmotic, motility-related, exudative, Inflammatory, infectious and other diarrhoea (WebMD, 2010). Motility-related diarrhoea is caused by the rapid movement of food through the intestines (hypermotility). If the food moves too quickly through the gastrointestinal tract, there is not enough time for sufficient nutrients and water to be absorbed. Diarrhoea can be treated with anti-motility agent like loperamide (Generic Name: Loperamide hydrochloride) is effective at reducing the duration of diarrhoea (Bruyn, 2008). With anti-motility diarrhoea properties of this synthetic chemical, it's but not free from side effects. So, the investigation of some herbal plants with antidiarrhoeal activity prerequisite like herbal sage tea Salvia officinalis L. to evaluation this potential activity of its anti-motility-related diarrhoea.

Salvia officinalis L. called sage is a popular plant belongs to the family of Labiatae and native to the Mediterranean region. Sage used as herbal tea and for food flavoring (Chalchat et al., 1998). Also is a valuable medicinal plant, which is used widely in traditional medicine. This plant species enjoys the reputation of being a panacea because of its wide range of medicinal effects: it has been used as an antibacterial (Yinrong. \& Yeap, 2002), antifungal (Tomás-Barberán, 1986), antiviral (Abad et al., 1997), anti-inflammatory (Recio et al., 1995) and antihidrotic, spasmolytic, antiseptic and in the treatment of mental and nervous conditions activities (Baricevic \& Bartol, 2000). 
However, there are no scientific studies available on the anti-motility-related diarrhoea effect of Salvia officinalis L. although this plant is used as a folk remedy as a digestive medicine to treat upset stomachs, flatulence and diarrhea. Therefore, anti-motility-related diarrhoea effect of sage was investigated in this study in laboratory mice.

\section{Materials and Methods}

\section{1 laboratory animals}

Fifteen male Balb/c mice, 3 months old, weighting 20 to $30 \mathrm{~g}$ were used for this study. The animals were purchased from Animal House / Centre of Drug Control / Ministry of Health, Baghdad, Iraq and acclimated to our laboratory animal facilities in animal house/faculty of Science/Wasit University for at least one week before the start of the experiments. During this period, the animals were housed in standard cages, maintained on a natural light/dark cycle at $20 \pm 2^{\circ} \mathrm{C}$ and given rodent food and tap water ad libitum.

\subsection{Plant material and preparation of sage tea}

Sage Salvia officinalis L. plants were purchase from the local market of Al-Kut city, Wasit province, Iraq. A specimen has been classified at lush vegetation of the Iraqi National Council /the Ministry of Agriculture, Iraq. The aerial parts of plants were lyophilized and kept a $-20^{\circ} \mathrm{C}$. The sage tea was routinely prepared by pouring 150 $\mathrm{ml}$ of boiling water onto $2 \mathrm{~g}$ of the dried plant material and allowing steeping for $5 \mathrm{~min}$ (Lima et al., 2005).

\subsection{Experimental design}

\subsubsection{Castor oil induced diarrhea}

The Procedure performed as per Kasture (2006). The animals were Fasted for 18 hours and divided into three groups of five animals per group. The animal groups were induced for motility-related diarrhoea by castor oil Castor oil (INTER Pharma laboratories), Syria before received any treatment vehicles. The first group (positive control group) received castor oil $(1 \mathrm{ml} /$ mouse $)+$ distilled water $(0.2 \mathrm{ml} /$ mouse $)$ orally, the Second group (negative control group) orally received castor oil $(1 \mathrm{ml} /$ mouse) followed by Loperamide Hydrochloride, Manufacturer: DIALUM $\odot$, Mission Vivacare Ltd., India (equivalent $0.171 \mathrm{mg} / \mathrm{kg} \mathrm{B}$. W.) after one hour and the third group (treatment group) orally received castor oil ( $1 \mathrm{ml} /$ mouse) followed by (dose volume $4.28 \mathrm{ml} / \mathrm{kg}$ B.W. equivalent aqueous extract preparation of sage $60 \mathrm{mg} / \mathrm{kg} \mathrm{B}$. W.) after one hour.

\subsubsection{The purging index (PI):}

Animals from each group were placed in separate standard cages lined with blotting paper. The blotting paper were changed hourly and examined after every thirty min, for presence of diarrhoea for up to 6 hours. The latency to defecate stools in each mouse showing diarrhoea in each group was recorded, the purging index (PI) was calculated by the following formula (Kasture, 2006).

\section{$P I=\%$ responder $X$ average numbered of stools laverage latent period}

\subsection{Statistics}

Data were entered into Vassar Stats: Website for Statistical Computation (VASSAR STATS, 2011). Data were expressed as (Mean \pm S.E.M.). Student t-test was used for the evaluation of values and $P<0.05$ was considered to be statistically significant.

\section{Results and Discussion}

As can be seen from table 1, the current findings of observation for six hours after orally castor oil administration, all the mice in the groups $\left({ }^{+\mathrm{ve}}\right.$ control, ${ }^{-v e}$ treatment, and sage tea treatment) produced severe diarrhea with $100 \%$ responder. In this context, the castor oil induced diarrhoea model was adopted as the autacoids and prostaglandins are involved in causation of diarrhoea. The liberation of ricinolic acid from castor oil result in irritation and inflammation of intestinal mucosa, leading to production of prostaglandins, which stimulate intestinal motility and secretion (Gatne et al., 2008).

The aqueous extract of Salvia officinalis $\mathrm{L}$. caused a significant $(\mathrm{p}<0.05)$ decreasing of stools number $(1.24$ $\pm 0.19)$ as compared to the positive control and negative treatment (loperamide) groups (5.40 \pm 0.81 and 2.00 \pm 0.32 ) respectively, as well as our study showed a remarkable significantly reduction on the latency period to defecate severity of the diarrhea after orally administration of sage extract $(0.90 \pm 0.10)$ as compared to negative treatment (loperamide) group $(1.30 \pm 0.20)$. Although, loperamide drug is a synthetic antidiarrheal acts by slowing intestinal motility and by affecting water and movement through the bowel. Loperamide binds to the opiate receptor in the gut wall. Consequently, it inhibits the release of acetylcholine and prostaglandins, thereby inhibitory influence on gastric and small bowel peristaltic activity manifests in increased gastrointestinal transit 
time (GITT), one of the major determinants of drug absorption. In addition, loperamide increases the tone of the anal sphincter, thereby reducing incontinence and urgency. It has potent inhibitory action on gastrointestinal motility and gastric secretion (Heel et al., 1978; Sundhu et al., 1981).

Salvia officinalis L. extract has been shown a marked anti-motility related-diarrhoeal effect as evidenced by the reducing in the purging index in sage treatment group (137.78) as compared to the other groups, positive control and negative treatment (loperamide) (254.72 and 153.85) respectively (figure 1) might due to the special phytostructure of S. officinalis L. against motility-related diarrhoea. So, this an anti-diarrheal properties may be belong to sharing out some bioactive compounds are found in the sage tea S. officinalis L. that possess an inhibitory action of diarrhoea such as an essential volatile oil, flavonoids, phenolic acids, resin, saponins, Thujone, silica, and tannins (Blumenthal, 1998). In this context, the volatile oils have a relaxant effect on the smooth muscle of the digestive tract, while in conjugation with the bitters; they stimulate the appetite and improve digestion. Sage encourages the flow of digestive enzyme and bile, settles the stomach, relieves colic, wind, indigestion, nausea, diarrhea and colitis, liver complaint, and worms. Its antiseptic properties are helpful in infection such as gastroenteritis (HERBALPEDIA, 2000). Furthermore, antidiarrheal properties of some medicinal plants were found to be due to tannins, flavonoids, alkaloids, saponins, reducing sugar, sterols and/or terpenes (Longanga Otshudi et al., 2000; Venkatesan, 2005). The antidiarrheal activity of flavonoids has been ascribed to their ability to inhibit intestinal motility and hydro-electrolytic secretion which are altered in this intestinal condition. In vitro and in vivo experiments have shown that flavonoids are able to inhibit the intestinal secretory response induced by prostaglandins E2 (Di Carlo et al., 1993). Furthermore, during experimental observations of the sage group did not record any side effects and returned noticeably to eat rodent food and drinking water routinely compared to the rest of the positive and negative groups were associated with the purging index.

\section{Conclusion}

The findings of this study revealed that extract of sage tea $S$. officinalis L.possess an inhibitory action on motility-related diarrhoea may attributed to therapeutic properties of this plant which contains pharmacologically active substances with antidiarrheal properties and advised to use in traditional medicine safely. Further research is requested to investigate the phytochemical analysis of bioactive compounds are responsible for the anti-motility-related diarrheal activity observed of this herbal plant.

\section{Acknowledgment}

Offer thanks and appreciation to the research project group of undergraduate students/fourth class in the department of Biology, college of Science, Wasit University, which contributed to the completion of this research.

\section{References}

Abad, M. J., Bermejo, P., Villar, A., Palomia, S. S. \& Carasco, L. (1997). Antiviral activity of medicinal plant extracts. Phytotherapy Research, 11 (3): $198 . \quad$ http://dx.doi.org/10.1002/(SICI)10991573(199705)11:3<198::AID-PTR78>3.0.CO;2-L.

Baricevic, D. \& Bartol, T. (2000). The biological/pharmacological activity of the Salvia genus. In: S. E. Kintzios (Ed.), SAGE - The Genus Salvia. Harwood Academic Publishers, Amsterdam, pp, 143-184.

Blumenthal, M. (1998). The Complete German Commission E Monographs: Therapeutic Guide to Herbal Medicines. American Botanical Council. Austin, TX.

Bruyn, G. (2008). "Diarrhoea in adults (acute)". Clin. Evid. Clin Evid. [Online] Available: http://www.ncbi.nlm.nih.gov/pubmed/19450323 (April 12, 2011).

Chalchat, J. C., Michet, A. \& Pasquier, B. (1998). Study of clones of Salvia officinalis L. yields and chemical composition of essential oil. Flavour Fragr. J., 13: 68-70. http://dx.doi.org/10.1002/(SICI)10991026(199801/02)13:1<68::AID-FFJ698>3.0.CO;2-8.

Di Carlo, G., Autore, G., Izzo, A. A., Maibline, P., Mascolo, N., Viola, P., Diurno, M. V. \& Capasso, F. (1993). Inhibition of intestinal motility and secretion by flavonoids in mice and rats: Structure activity relationships. J Pharmacol, 45: 1054-1059. http://dx.doi.org/10.1111/j.2042-7158.1993.tb07180.x

Gatne, M. M., Ghangale, G. R., \& Surve, V. S. (2008). Studies on Anti-diarrhoeal Activity of Ocimum sanctum (Thlsi) in Rats. J. Bombay Vet. Coll., 16 (1): 42-43. 
Heel, R. C., Brogden, R. N., Speight, T. M. \& Avery, G. S. (1978). Loperamide: a review of its pharmacological properties and therapeutic efficacy in diarrhea. Drug, 15: 33-52. http://dx.doi.org/10.2165/00003495-197815010-00003

HERBALPEDIA. (2000). Sage. [Online] Available: http:// www.herbnet.com/sage.pdf (April 16, 2011).

Kasture, S. B. (2006). A Hand Book of Experiments in Preclinical Pharmacology, first edition, career publications, Vakil wadi, Nashik-422001. Maharashtra. Cited by: Gatne, M. M.; Ghangale, G. R. and Surve, V. S. (2008). Studies on Anti-diarrhoeal Activity of Ocimum sanctum (Thlsi) in Rats. J. Bombay Vet. Coll., 16 (1): 42-43.

Lima, C. F., Andrade, P. B., Seabra, R. M., Fernandes-Ferreira, M. \& Pereira-Wilson, C. (2005). The drinking of a Salvia officinalis infusion improves liver antioxidant status in mice and rats. $J$. Ethnopharmacol., 97: 383-389. http://dx.doi.org/10.1016/j.jep.2004.11.029

Longanga Otshudi, A., Vercruysse, A. \& Foriers A. (2000). Contribution to the ethnobotanical, phytochemical and pharmacological studies of traditionally used medicinal plant in the treatment of dysentery and diarrhea in Lomela area, Democratic Republic of Congo (DRC). J Ethnopharmacol, 71(3): 411-423. http://dx.doi.org/10.1016/S0378-8741(00)00167-7

Recio, M.C., Giner, R.M., Manez, S., Rios, J.L., Marston, A. \& Hostettmann, K. (1995). Screening of tropical medicinal plants for antiinflammatory activity. Phytotherapy Research, 9(8): 571. http://dx.doi.org/10.1002/ptr.2650090807

Sundhu, B. K., Tripp, J. H., Candy, D. C. A. \& Harries, J. T. (1981). Loperamide: Studies on its mechanism of action. Gut 22:658- 662. http://dx.doi.org/10.1136/gut.22.8.658

Tomás-Barberán, F. A. (1986). The flavonoid compounds from the Labiatae. Fitoterapia, 57(2): 67-95.

VASSAR STATS [homepage on the Internet]. (2011). Vassar College Poughkeepsie, NY, USA. [Online] Available: http://faculty.vassar.edu/lowry/VassarStats.html (May 5, 2011).

Venkatesan, N., Thiyagarajan, V., Narayanan, S., Arul, A., Raja, S., Kumar S. G. V., Rajarajan, T. \& Perianayagam, J. B. (2005). Antidiarrheal potential of Asparagus racemous wild root extracts in laboratoire animals. J Pharm Pharmaceut Sc., 8(1): 39-45.

WebMD [homepage on the Internet]. (2010). The Basics of Diarrhea. [Online] Available: http://www.webmd.com/ digestive-disorders/digestive-diseases-diarrhoea (March 6, 2011).

World Health Organization (WH0). (2011). "Diarrhoea". [Online] Available: http://www.who.int/ topics/diarrhoea/en/ (April 5, 2011).

World Health Organization (WHO). (2009). [Online] Available: http:// whqlibdoc .who. in/publications/ 2009/9789241598415_eng. pdf (April 9, 2011).

World Health Organization (WHO). World Health Report. (2004). Geneva, pp, 120-125.

Yinrong, L. \& Yeap, F. L. (2002). Polyphenolics of Salvia- a review. Phytochemistry. 59(2):117-40. http://dx.doi.org/10.1016/S0031-9422(01)00415-0

Table 1. Effect of sage tea S. officinalis L. on castor-oil induced motility-related diarrhoea in mice

\begin{tabular}{|c|c|c|c|}
\hline Group & $\begin{array}{c}\text { \% Responder for } \\
\text { diarrhoea }\end{array}$ & $\begin{array}{c}\text { Latency period in } \\
\text { hr. }\end{array}$ & $\begin{array}{c}\text { Number of stools } \\
\text { a }\end{array}$ \\
\hline${ }^{+v e}$ Control & 100 & $2.12 \pm 0.10$ & $5.40 \pm 0.81$ \\
\hline $\begin{array}{c}\text {-ve } \text { Treatment } \\
\text { (loperamide) }\end{array}$ & 100 & $1.30 \pm 0.20^{*}$ & $2.00 \pm 0.32 *$ \\
\hline Sage tea treatment & 100 & $0.90 \pm 0.10^{*}$ & $1.24 \pm 0.19^{*}$ \\
\hline
\end{tabular}

a Values represent Mean $\pm \operatorname{SEM}(n=\mathrm{n})$

$* \mathrm{P}<0.05 \mathrm{vs}^{+\mathrm{ve}}$ control group. 


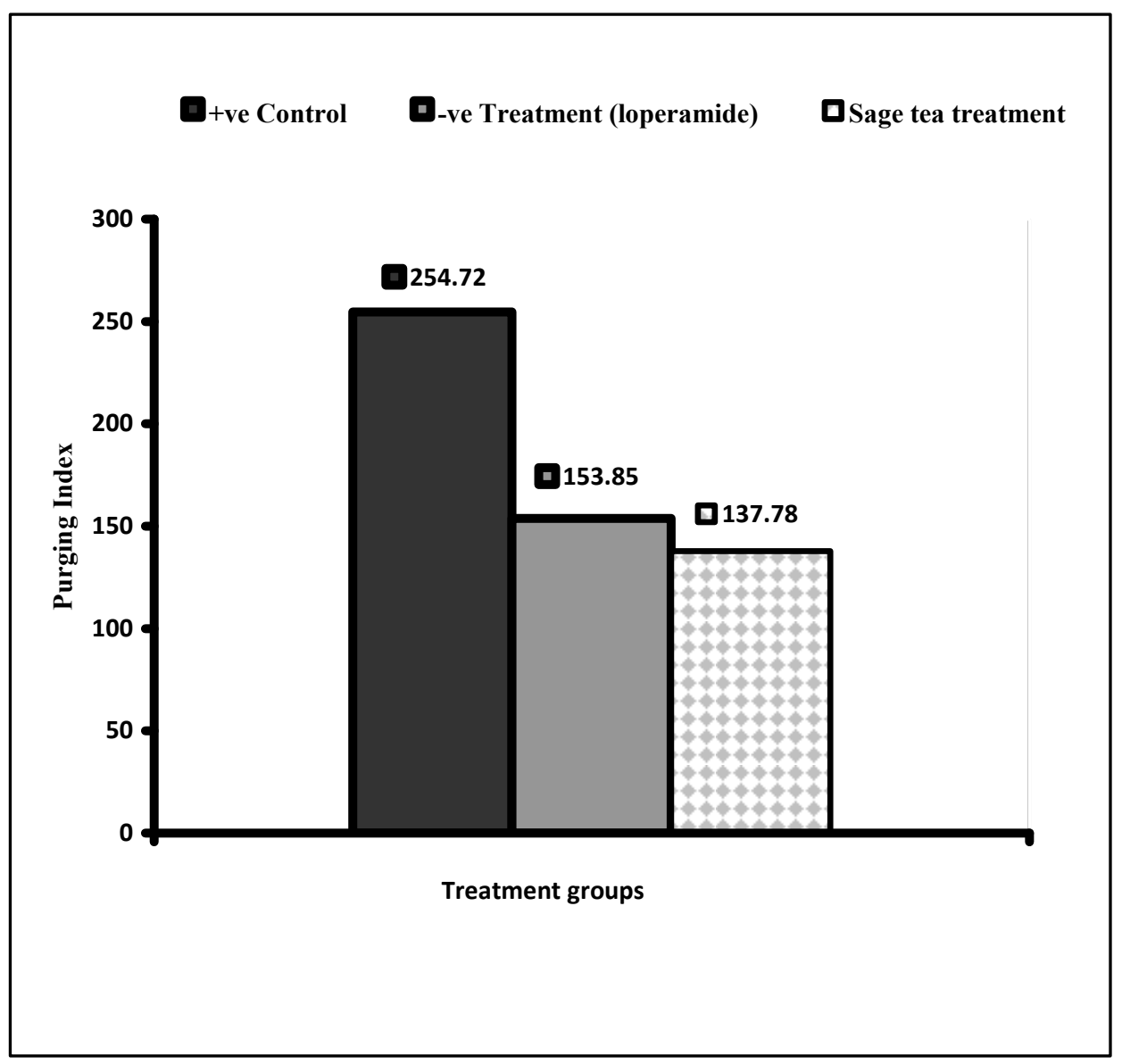

Figuer 1. The purging index of sage tea S.officinalis L. effect on castor-oil induced motility-related diarrhoea in mice 